RESEARCH PAPERS

\title{
Second World War Archaeology in Schools: A Backdoor to the History Curriculum?
}

\author{
Gabriel Moshenska \\ UCL Institute of Archaeology
}

\begin{abstract}
The absence of a compulsory archaeological element in the English National Curriculum is a systemic weakness, and a problem for archaeological educators. However, historical or post-medieval archaeology offers the opportunity to make connections with the existing history curriculum at various stages, thereby introducing elements of archaeological methods and concepts into classrooms. In this paper I consider the potential for Second World War archaeology in or around the school building itself to involve students in archaeological fieldwork integrated into the National Curriculum, specifically history at Key Stage Two. Drawing on a case study of a school air raid shelter excavation in North London I examine the strengths and weaknesses of this model and discuss the scope for its broader application.
\end{abstract}

\section{Keywords}

Community archaeology, education, historical archaeology, National Curriculum, Second World War

\section{Introduction}

The challenge of teaching primary school students about archaeology is made more difficult in England by the limitations of the National Curriculum for history, which delineates what is taught in schools (National Curriculum 2008). Although there are optional units on the Indus Valley civilisation, the Romans, Vikings and others, and visits to historic sites are theoretically encouraged, there is little opportunity for primary school students to observe or engage with archaeological materials and processes. This is one of the main stumbling blocks in campaigns for lifelong learning in archaeology promoted by the Council for British Archaeology (CBA) and others (Henson 2004a).

Post-medieval or historical archaeology, along with industrial archaeology, offer a unique opportunity for school students to encounter the archaeological process in the context of historical periods and local sites which they are more likely to be familiar with already. The advantages of such work would be numerous, including the potential for more diverse teaching and learning techniques as well as connections with local history and oral history work. It also sidesteps many of the common objections to doing archaeology with young children (see Pretty 1983: 14).

In this paper I will focus specifically on the archaeology of the Blitz in English schools, particularly the archaeological and educational potential of the school air raid shelter. This includes a discussion of the Second World War unit in history at Key Stage Two (hereafter KS2), and the strengths and limitations of the archaeological resource in question. My case study is taken from a project to excavate and clear a large air raid shelter located beneath the playing field at Edgware Junior School in North London. This project included elements of historical documentary research and oral history in-

Papers from the Institute of Archaeology 19 (2009): 55-66 
terviewing as well as the survey and excavation. It also involved classroom and sitebased learning for the school students, including but not limited to students who had studied the Second World War the previous term.

In concluding I critically examine this case study in relation to the issues raised earlier, and discuss the strengths and weaknesses of this approach to archaeological education. First, however, I will consider in more depth the state of archaeology in the National Curriculum for history at KS2.

\section{Archaeology in the National Curriculum}

[Archaeology] cannot be accepted by society as a useful discipline, worth fostering and protecting, if we set ourselves above that society as the intellectual few acting on behalf of the ignorant many. In this, we need to learn the lessons of the school curricula, which seek to equip pupils not just with historical knowledge but also with the skills to make their own judgements and interpretations (Henson 2004b: 30).

Archaeology graduates usually find it difficult if not impossible to get accepted onto teacher training courses, as archaeology is not a curriculum subject and is generally not taught in schools. The paucity of archaeological knowledge amongst school teachers thereby becomes a self-perpetuating problem (Corbishley 1999: 77). The CBA campaigns actively both for greater levels of archaeological education in schools and better access to teaching for graduates, but progress is slow.

However, all is not lost. There are plenty of areas in England's history curriculum where archaeology can be introduced by sympathetic and knowledgeable educators, given the right resources, support and encouragement. Across the different Key Stages teachers are encouraged to promote the use of non-documentary sources including artefacts, buildings and historic sites (Henson 2004a). In this way the guidelines, if followed, expose students to historical material culture in the broadest sense allowing them to consider issues of archaeological interpretation, although the archaeological process itself remains in the background. In addition school trips to museums and sites are increasingly hampered by child protection and health and safety issues. However as Dhanjal (2005: 37) has observed, "It is easier to fit archaeology into the KS2 curriculum, and it is easier for teachers to take this age group on school outings". There is also the option for students at KS1 and KS2 to carry out units on past societies including the Romans and Mesopotamia; in addition the changes to the curriculum in 2000 introduced a modicum of prehistory into KS2 history. Nevertheless archaeology is not generally considered in relation to these topics until KS3 at the earliest, if at all (Henson 2004a: 16; 19).

History in schools is an integral element of the citizenship agenda in education, a recent and altogether sinister development in the curriculum. However, such exercises in jingoistic chauvinism are likely to include archaeological elements, with a stronger focus 
on prehistoric sites and artefacts that reinforce nationalist mythologies. This is a high price to pay for archaeology in the curriculum, and one that in my opinion archaeological educators should not rush to embrace. For more detailed and broader discussions of archaeology in the curriculum see Corbishley (1999) and Henson (1997; 2000).

\section{The Second World War in the History Curriculum}

The 2007 History Schemes of Work for primary school students at KS2 includes 'Unit 9: What was it like for children in the Second World War?' (DfES 2007). This is a popular unit, drawing on a wide range of resources including museums and children's literature. Local history is a strong element in this unit, making the subject more immediately relevant to the students: teachers are encouraged to arrange visits from older local residents to talk about their experiences, supplemented by local history publications such as published oral histories. The unit of the Scheme of Work covers ten distinct areas of study:

1. What was the Second World War? When and where did it take place?

2. What was the Blitz?

3. Why were children evacuated?

4. What was it like to be an evacuee?

5. What did people eat during the war?

6. In what other ways might the war have affected people?

7. What were children's experiences of the war?

8. What was it like to be a child living in this area in World War II?

9. How did the Second World War affect children who lived in this locality?

10. What has been done since to prevent another world war?

(DfES 2007)

These sections and the emphasis on children's experiences demonstrate an overwhelming and arguably disproportionate focus on the Home Front, rather negating the idea of a world war which is only tackled at KS3 and KS4. Nevertheless, this structure is ideally suited to integration into local history and archaeology. The guidance for section two on the Blitz includes the suggestion that "It may be possible to show children local evidence of bomb damage, e.g. damaged buildings, derelict land, prefab housing" (DfES 2007). It is not immediately taken into consideration that the fabric and grounds of the school itself might contain a great deal of evidence linking it to the narrative history of the war. However 'Learning Outside the Classroom', a recent initiative promoted by the Department for Children, Schools and Families (DCSF), encourages the use of the school grounds and buildings as resources for formal and informal learning (DfES 2006).

A historical archaeology of the Second World War is highly likely to be interdisciplinary, applying a range of research techniques to any specific site or locale. These techniques, including building survey, documentary research, oral history interviews and topographical surveys are similar or identical to many of the techniques discussed in the guidance for teachers. Clearly there is potential for cooperation, but it must be 
noted even at this point that any archaeological education based on this work will need to emphasise the diversity of archaeological research in pre- and proto-historic as well as more recent historic periods to avoid confusion and false impressions. This and similar points were raised by Starmer (1983) in his discussion of industrial archaeology for schools.

\section{The Archaeological Resource: Schools at War}

School buildings in Britain are very likely to contain traces of modifications and use dating from the Second World War. This is largely due to the confusion and changes in government policies on evacuation during the earliest months of the war in 1939 and 1940. The policy of evacuating up to 1.5 million school students and their teachers, as well as pregnant women, was planned months in advance and put into effect at the outbreak of hostilities (Calder 1969). However, during the quiet first months of the war when very few cities were bombed, the so-called 'phoney war', a large proportion of the urban evacuees began to return home from their safe rural reception areas.

Most of these children returned to find their schools closed, apparently for the duration, with responsibility for the buildings often passing to the local Air Raid Precautions administrations, fire brigade, the military or similar (Hussey 2003). However, as the realities of the numbers of returning evacuees began to sink in, schools began to reopen. Even before the war the Board of Education had released circulars advising on modifications to school buildings to provide safe areas for air raids. However, these guidelines recognised the lack of suitability of many school buildings and advised the construction of air raid shelters on school playing fields, neither too near nor too far from the school itself. The rules for the construction of the shelters are quite rigid, specifying their height, means of drainage, gas-proofing and roofing, as well as the amount of seating space per child. The most important limitation was on capacity: no more than fifty children were to be sheltered in any one structure or room, presumably to minimise casualties in the event of a direct hit (Board of Education 1939). In the post-war period most local councils were instructed to seal the school and other municipal air raid shelters for possible future use. Some have since been destroyed by development, but many remain as time-capsules from the 1940s, waiting to be discovered.

On the basis of these convoluted processes and events, schools of a certain age are likely to contain evidence of wartime modifications in a number of respects. They might contain the remnants of modifications carried out in 1939 to convert them into gas de-contamination centres, Air Raid Precautions operations centres, emergency fire stations, casualty clearing stations or any number of military uses (O'Brien 1955). In addition they are more than likely to have basement rooms modified for air raid protection or air raid shelters or the remains of shelters on or beneath the playing fields. The archaeological potential of these structures is worth considering from both a research perspective and pedagogical one. The following case study demonstrates the possibilities of combining these approaches, offering a community archaeology of the Second World War for school students, in school and with the school. 


\section{Case Study: Edgware Junior School}

Civil Defence is a neglected area in British battlefield archaeology; Coad asks "what survives of the huge public and private shelter-building programme?" and concludes that "the tangible evidence for... 20th-century warfare, with all that it can teach us about the horrors of modern weaponry, is apparently now surprisingly scarce" (2005: 231). Schofield's research agenda for modern military sites raises the idea that civil defence sites lend themselves to "project work, where local sources can be compared to field remains, and oral testimonials" (2004: 46). This is precisely what we set out to do at Edgware Junior School, and a short report on the project has subsequently been published (Moshenska 2007). It is important to note that the impetus for this project came from the school teachers who identified the site, decided to investigate further, and contacted the local archaeology society for advice, at which point our involvement began.

The outline of a concrete structure, later identified as a staircase, had been gradually revealed at the side of the field by soil erosion. While staff at the school were aware that air raid shelters had been built there, their exact locations had remained unknown; I visited the school and the project was born in discussion with staff. The principal aims of the project were to evaluate the structure and contents of the shelter, and to use it as a resource for teaching students about the Second World War, which Year 6 students (aged 10 to 11) study in the autumn term. As a community archaeology project the shelters were ideal, and there was enthusiastic support for the work from the staff, grounds staff and students. The educational aims were less ambitious but nonetheless unusual in the circumstances: I intended to use the site to teach the students about archaeological methods and fieldwork practices, backed up by presentations. The Year 6 students' prior knowledge of the Second World War would be used as the basis for classroom sessions. The connections between the historical period and the archaeological methods were intended to be clear, but it was also vital to emphasise the importance of historical and oral sources, and the interconnections between the three.

\section{Historical Sources}

The school log-book recorded events at and around the school throughout the war, including air raid drills and bombing; this was one of the most useful historical sources for this research. The Barnet Archives, encompassing the archives of the old Hendon Borough Council, were of great use: the minutes of the education committee together with the borough engineer's reports give an excellent record of civil defence provision in local schools. Board of Education circulars were also consulted as relevant, and the Imperial War Museum library provided an excellent series of sources on air raid shelters. In retrospect this element of the research could have been communicated to the students earlier and more fully, but it was felt at the time that archival work was not as racy or spectacular as the excavation work it inevitably precedes by some weeks or months. In the event a summary of the process of archival work was included in the information given to students at the excavation site during the fieldwork itself.

From the sources we know that the school was used as a fire station during the war, as they record $£ 432$ compensation for damage to the school by the National Fire Service (Hendon Education Committee 1946), and one of the exterior walls has a sign reading 
'WATCH ROOM' painted on it (Fig. 1). However, the school did not stay closed long: from the outbreak of war in September 1939 classes were taught for a time in homes and local church halls. The construction of shelters began almost immediately, and as they were completed classes gradually returned to Edgware School; by early 1940 six shelters were completed and a further seven were later added (Edgware School Logbook 1940). Over the following years the shelters were adapted and renovated including the provision of lighting, seating, chemical toilets, heating and ventilation. The aims of these modifications were to allow teaching to continue in the shelters, as more and more lessons were interrupted by air raid warnings (Hendon Education Committee 1941). A cutting from the Evening Standard shows a class being taught geography in one of the shelters at Edgware School sometime in 1940. Following the cessation of hostilities, the shelters at Edgware School were stripped out and sealed with concrete by the borough engineer. Nowhere in these sources is there any indication of the location, type or construction methods of the school air raid shelters. To answer these questions and to evaluate the state of the shelters we began to survey and excavate the site.

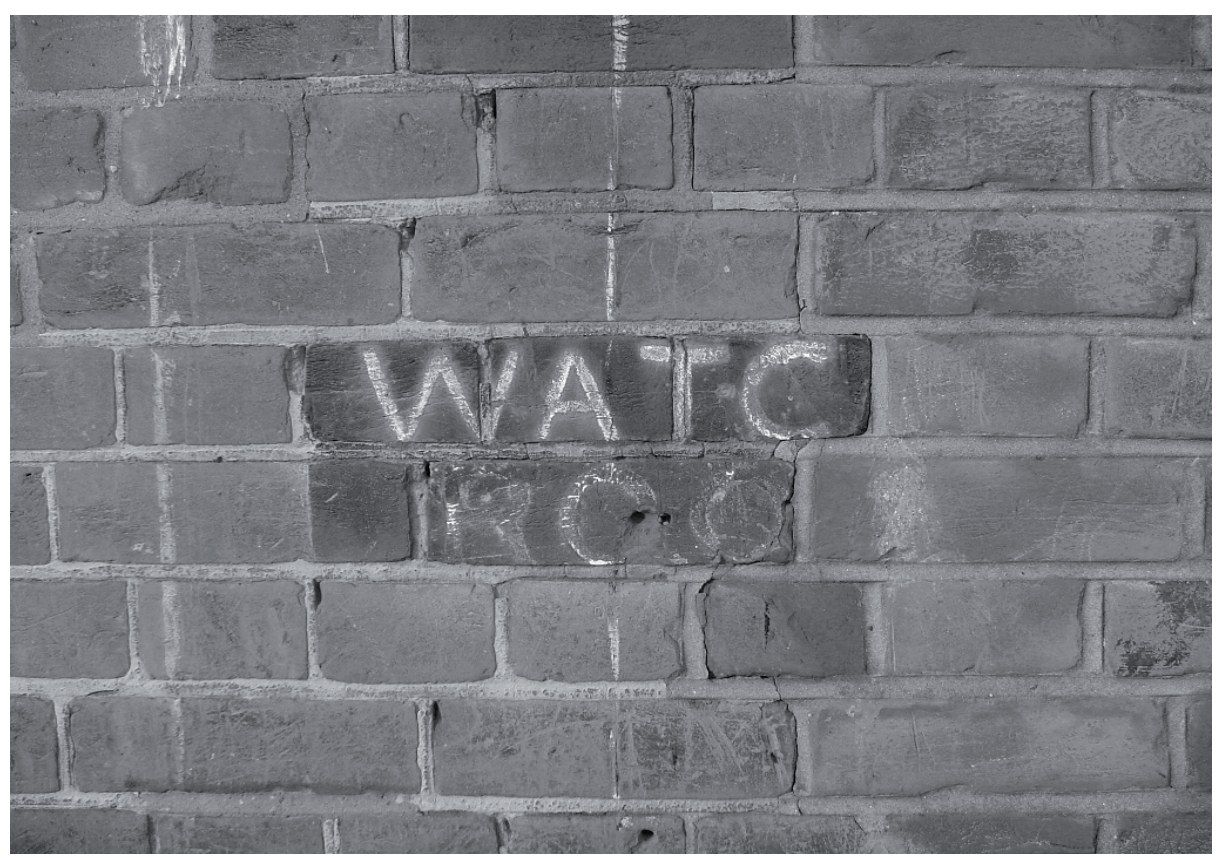

Figure 1. WATCH ROOM: painted sign on the wall of a school building.

\section{Excavation and Survey}

A resistivity survey was carried out some months before the excavation on the school field where the shelter is located, revealing a further seven shelters beneath the grass football pitch. A few school students were present and we explained our strange activities as far as we could. At this point the project was still speculative and we had no coherent educational aims. In any case, the principles of resistivity are probably not the best place to begin the archaeological education of young children or, indeed, anyone else. 
The subsequent excavation of the air raid shelter was in two parts: the main project was to clear the soil that sealed the concrete staircase (Fig. 2); the second was a smaller trench designed to expose the roof of the shelter from above. The purpose of the second was twofold: partly to illuminate methods of construction and waterproofing, but mainly to provide an example of more typical archaeological excavation with a regular rectangular trench dug in layers, rather than a concrete-lined hole with a uniform fill of rubble and mud. As well as the roof of the shelter at a depth of half a metre, the trench produced fragments of medieval and post-medieval pottery and a halfpenny dating to 1852.

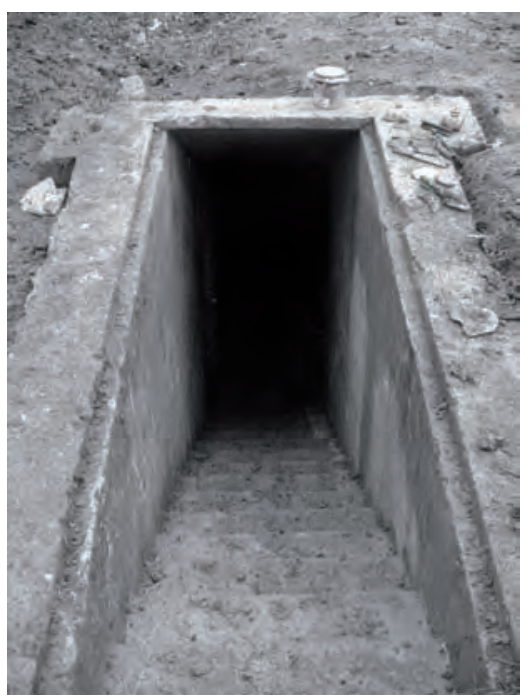

Figure 2. The entrance of the shelter, following excavation.

In the first three days of the excavation all of the school students were brought out by teachers and classroom assistants, one class at a time, to see the work in progress and to have it explained to them. These talks, illustrated with artefacts, were presented by the UCL Institute of Archaeology Widening Participation and Diversity Officer who was assisting with the project (Fig. 3). The talks were interactive and included some lively discussions that revealed some surprising levels of knowledge about both archaeology and the Second World War.

Once the staircase was cleared we were able to gain access to the shelter; an exciting moment! The structure was fifteen metres long and around two metres wide and high. The interior was rather bare, containing metal fittings for seats and toilet cubicles at either end. There were the remains of electrical fittings on the walls, and a free-standing gas heater was found buried at the bottom of the stairs. Most interestingly there were a series of maths problems chalked on the end wall of the shelter, clear evidence that it had been used as a classroom with lessons continuing during the air raids. The only 
other graffiti we discovered was an image of a sailing ship in yellow chalk or crayon on one of the side walls.

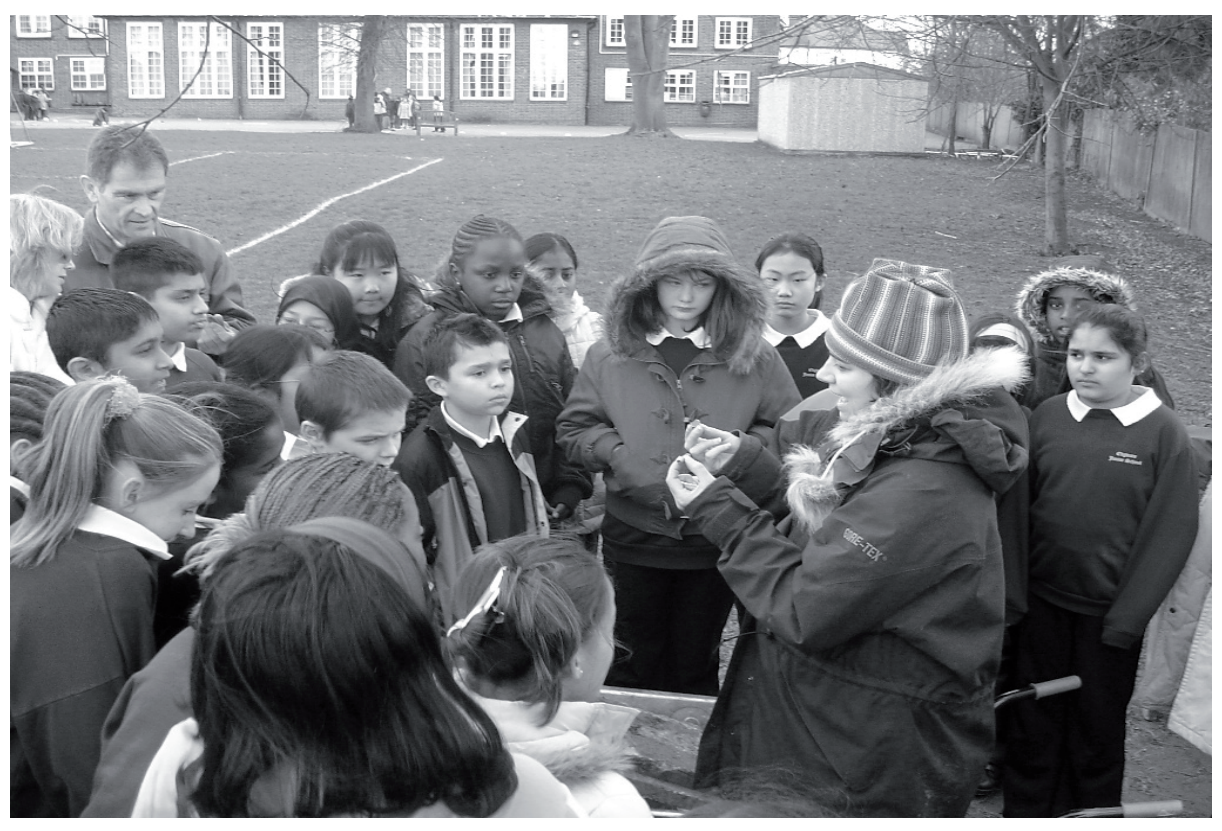

Figure 3. Explaning the archaeological process on site.

For health and safety reasons the school students were not allowed to go below ground during the survey and excavation; indeed we made sure they never came within $1.5 \mathrm{~m}$ of the sides of the trench. However, once the structure had been judged to be safe the school allowed a small group of students to enter. There was a great heap of rubble and rubbish at the end furthest from the staircase beneath the sealed emergency exit, and it was decided in consultation with the school that some of the students should be allowed to excavate this under close supervision. The rubbish heap yielded some remarkable artefacts including children's toys, car parts, glass bottles and jars, and assorted shoes and items of clothing. In these circumstances health and safety was of vital importance and all appropriate precautions were taken.

\section{Memory Work}

In the middle of the excavation we arranged for Mrs Tessa Smith who had been a student at the school during the war to visit the site so that she could see the shelter, record an oral history interview and talk to the students about her memories of wartime education. We recorded over an hour of interviews with Mrs Smith in a number of places: around the excavation, walking through the playground, and in a classroom. The interviews covered her childhood in general, her memories of the war and her memories of the school, which were wonderfully sharp and irreverent. 
During the interviews in the playground we were repeatedly approached by groups of children who had already seen the excavation and been told about Mrs Smith's visit. They were politely curious and asked a series of questions, some of a very high standard such as "Do you remember what it smelt like in the shelter?", "How old were you in the war?" and "Were you scared?" (Fig. 4). The spontaneity of these questions and the intense interest they demonstrated were both surprising and rewarding. I would argue that the sense of the excavation as an exciting and unusual event or performance had created more of a buzz around the school than an ordinary history project could have.

The final part of the interview took place in a classroom with a Year 6 class who had recently studied the Second World War and carried out a project, which had included covering windows in criss-crossed tape as they had been in 1940. In this case the questions were more orderly and better informed, albeit in curious ways. The students had clearly absorbed a great deal from the fiction they had read, particularly Robert Westall's The Machine Gunners and Michelle Magorian's Goodnight Mr Tom. This was expressed in some strange questions such as "Did you ever find a German plane with a dead person in it?". However most of the questions were more focused on changes to the school since 1945 and issues such as rationing, evacuation and bombing, as well as life in the air raid shelters. The teacher handled the session sensitively; in any case Mrs Smith had worked as a teacher before her retirement so her manner in dealing with the students was expert.

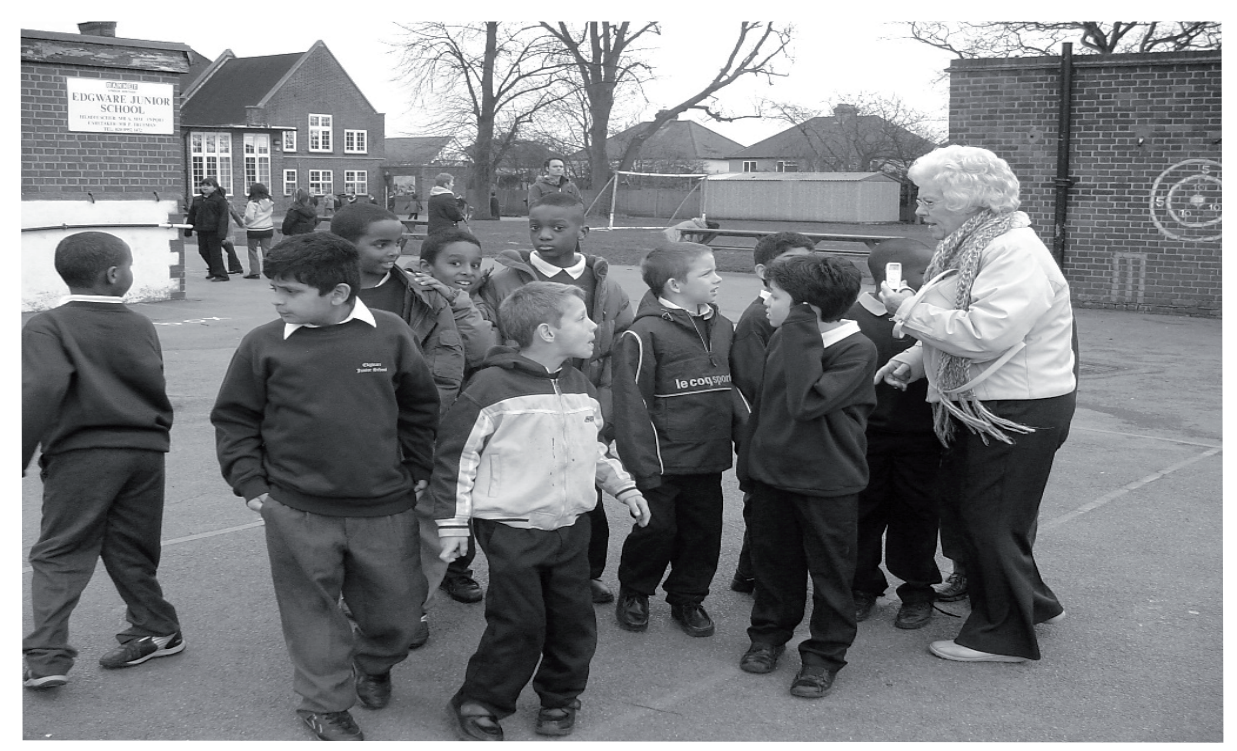

Figure 4. Impromptu oral history work in the playground.

\section{Archaeological Education}

During the visits to the site we explained the basics of archaeological fieldwork practice to the students. We pointed out earthworks visible on the surface, and briefly explained 
that we have machines that can see different things under the ground. To draw these disparate elements together into a more coherent understanding of the project we arranged for the UCL Institute of Archaeology Widening Participation team to give an assembly presentation to the entire school on "What is Archaeology?" This explained why we dig under the ground to find artefacts and sites that help us learn about people's lives in the past.

The presentation discussed a range of different periods and places where archaeology might be a useful way to investigate things. We felt this was particularly important to avoid giving students the impression that historical archaeology was anything more than a small part of a wider field, and to emphasise the value and importance of archaeological research in prehistoric periods.

The overall experience from the students' perspective was hopefully a useful and wellrounded one, although this analysis is inevitably subjective. The muddy process they had witnessed and had briefly introduced to them was further explained within a wider context of studying the past and particularly the distant past. For the Year 6 students the value was multiplied, as the entire project was linked to their most recent studies and placed it within an environment they were familiar with.

While the archaeological element of the project was highly satisfactory there were aspects of the education element that with hindsight I would have done differently. The assembly and possibly some classroom based sessions on archaeology for the older students might have been of greater value if carried out before rather than during the excavation; this has proved more successful in subsequent projects. It might have been possible to involve the students more fully in the excavation if time, tools and teachers had allowed us to excavate some of the interesting lumps and bumps on one side of the field that appeared to be entrances to air raid shelters much closer to the surface, and less likely to involve dangerously deep trenches. I believe that a greater degree of involvement in the excavation, again for the older students, would have made a more lasting impact and helped spark an interest that might be developed through informal means, such as the Young Archaeologists' Club. In the event two students expressed an interest in finding out more about archaeology and we provided them with the appropriate website information to find out more. Finally, since carrying out this excavation project I have heard of some similar work carried out elsewhere in the country, as well as plans for another project of this type in the future. Sadly I was unable to draw any lessons or guidance from the former; hopefully I will be able to provide something of use to the latter.

\section{Conclusions}

Archaeologists should encourage schools to gather the evidence and use it to carry out curriculum work instead of just using a visit to an excavation or monument as an addition to the study of a particular period (Corbishley 1986: 8). 
Is the archaeology of Second World War schooling a cunning way to sneak archaeology into the history curriculum? Should the massed ranks of archaeological educators descend on schools everywhere and merrily hack chunks out of the playing fields and playgrounds in search of air raid shelters? Perhaps, and perhaps not.

On the positive side, bringing archaeology into school grounds is an excellent way of enthusing students and teachers about the potentials of archaeological studies of the past. Furthermore excavating a reinforced concrete air raid shelter is more amenable to student participation than, say, a Mesolithic site: a structure designed to withstand explosions can survive violent trowelling or inept mattocking without complaint. With active support from history teachers and head teachers, and most importantly the caretaker and grounds staff, such projects can be enormously rewarding for all concerned. Forward planning and archival research are obviously essential parts of this process at the early stages, not least in providing a historical background that is vital if integration into the curriculum is to be a central aim. The lasting result of such research should be a resource that can be used and reused over time.

However as mentioned earlier care must be taken to ensure that students understand the full breadth of archaeological research, temporally and geographically as well as thematically; for example building surveys are a good starting point to explain that not all archaeology is about digging. Another potential difficulty with the type of project described above is matching teachers' enthusiasm and openness with the availability of the resource. There are also innumerable logistical limitations but these apply in different ways in almost any community archaeology project. The biggest problem to overcome is how to develop students' interests in archaeology beyond outreach work: until archaeology has a firmer foothold in the school curriculum these individual projects run the risk of isolation. But as long as we understand them to be aspects of a broader campaign for archaeological education, there is no doubt that Second World War archaeology can become a useful tool amongst the techniques and approaches available to community archaeologists.

\section{Acknowledgements}

Many thanks to Sarah Dhanjal and Don Henson for their generous advice in the preparation of this paper, and to the editors and referees for their comments. Thanks also to the staff and students of Edgware School and to everyone who took part in and supported the excavation.

\section{References}

Board of Education. 1939. Circular 1467, 27th April. London: HMSO.

Coad, J. 2005. Warfare and Defence: What's Next? Post-Medieval Archaeology 39(2), 224-232.

Calder, A. 1969. The People's War: Britain 19391945. London: Cape.

Corbishley, M. 1986. Archaeology, Monuments, and Education, in Cracknell, S. and Corbishley, M. (eds.) Presenting Archaeology to Young People. York: CBA Research Report 64, 3-8. 
Corbishley, M. 1999. The National Curriculum: Help or Hindrance to the Introduction of Archaeology in Schools? in Beavis, J. and Hunt, A. (eds.) Communicating Archaeology. Oxford: Oxbow, 71-78.

DfES, 2006. Learning Outside the Classroom Manifesto. [http://publications.teachernet.gov.uk/eOrderingDownload/LOtC. pdf] [Accessed 19.1.08].

DfES, 2007. History at Key Stages 1 and 2. Unit 9: What was it like for children in the Second World War? [http://www.standards.dfes.gov.uk/schemes2/history/ his9/?view=get] [Accessed 19.1.08].

Dhanjal, S. 2005. Touching the Past? Papers from the Institute of Archaeology 16: 35-49.

Edgware School Logbook. 1940. Entry 18th November: Edgware: Edgware Junior School.

Hendon Education Committee. 1941. Minutes of Meeting 8th March. Barnet Archives.

Hendon Education Committee. 1946. Minutes of Meeting 10th September. Barnet Archives.

Henson, D. 1997. Archaeology in the English National Curriculum. York: CBA.

Henson, D. 2000. Teaching the Past in the United Kingdom's Schools. Antiquity 74, 137-41.

Henson, D. 2004a. The Educational Framework in the United Kingdom, in Henson, D., Stone, P. and Corbishley, M. (eds.) Education and the Historic Environment. London: Routledge, 13-21.

Henson, D. 2004b. Archaeology in Schools, in Henson, D., Stone, P. and Corbishley, M. (eds.) Education and the Historic Environment. London: Routledge, 23-32.

Hussey, S. 2003. The School Air-Raid Shelter: Rethinking Wartime Pedagogies. History of Education Quarterly 43(4), 517-539.

Magorian, M. 1998. Goodnight Mister Tom. London: Puffin.
Moshenska, G. 2007. Unearthing an Air-Raid Shelter at Edgware Junior School. London Archaeologist 11(9), 237-240.

National Curriculum. 2008. [www.nc.uk.net] [Accessed 23.1.08]

O’Brien, T. 1955. Civil Defence. London: HMSO.

Pretty, K. 1983. Not Child's Play: Excavation for Schools, in Corbishley, M. (ed.) Archaeological Resources Handbook for Teachers. York: CBA, 14-15.

Schofield, J. (ed.). 2004. Modern Military Matters: Studying and Managing the Twentieth Century Defence Heritage in Britain: a Discussion Document. York: CBA

Starmer, G. 1983. Industrial Archaeology for Schools, in Corbishley, M. (ed.) Archaeological Resources Handbook for Teachers. York: CBA, 9-11.

Westall, R. 1977. The Machine-Gunners. London: Puffin. 